\title{
ANALISIS SENYAWA FLAVONOID DAUN LAMUN Enhalus acoroides DI PERAIRAN PANTAI DESA WAAI KABUPATEN MALUKU TENGAH
}

\author{
Icak Darling Rahakbauw ${ }^{1}$, Th. Watuguly ${ }^{2}$, \\ ${ }^{1}$ Alumi Program Studi Pendidikan Biologi \\ ${ }^{2}$ Staf Pengajar Program Studi Pendidikan Biologi \\ E-mail: icat_darling@gmail.com
}

\begin{abstract}
Background: The coastal waters of Waai Village are the waters located in Kecamatan Kecamatan, Central Maluku District. The potential of coastal resources in this area is quite a lot of seagrass (Seagrass). Although quite a lot but because of the lack of information related to the existing seagrass so that until now the utilization of seagrass in the area has not been maximized. This study aims to determine the total flavonoid compounds contained in the seagrass of Enhalus acoroides.

Method: This research was conducted at Basic Chemical Laboratory, Faculty of Mathematics and Natural Sciences (FMIPA) Pattimura University Ambon. The study was conducted from March 20-28, 2016, with sampling location in coastal waters of Waai Village, Central Maluku District. The method used refers to the Chang method by using $\mathrm{AlCl} 3$ reagent.

Result: Based on total analysis of flavonoid compound using laboratory experimental method obtained the average flavonoid level contained in Enhalus acoroides seagrass leaves of $3.569 \%$.

Conclusion: Seaweed leaves Enhalus acoroides taken from coastal waters of Waai Village contain flavonoid compounds with an average value of $3.5697 \%$.
\end{abstract}

Keywords: Flavonoid, Enhalus acoroides

\begin{abstract}
Abstrak
Latar Belakang: Perairan pantai Desa Waai merupakan perairan yang berada di Kecamatan Salahutu, Kabupaten Maluku Tengah. Potensi sumberdaya pesisir yang ada di daerah ini cukup banyak diantaranya lamun (Seagrass). Walaupun cukup banyak namun karena minimnya informasi terkait lamun yang ada sehingga sampai saat ini pemanfaatan lamun di daerah tersebut belum maksimal. Penelitian ini bertujuan untuk mengtahui total senyawa flavonoid yang terkandung pada daun lamun Enhalus acoroides.

Metode: Penelitian ini dilakukan di Laboratorium Kimia Dasar, Fakultas Matematika dan IImu Pengetahuan Alam (FMIPA) Universitas Pattimura Ambon. Penelitian dilakukan mulai dari tanggal 20 28 maret 2016, dengan lokasi pengambilan sampel di perairan pantai Desa Waai Kabupaten Maluku Tengah. Metode yang digunakan mengacu pada metode Chang dengan menggunakan pereaksi $\mathrm{AlCl}_{3}$. Hasil: Berdasarkan hasil analisis total senyawa flavonoid menggunakan metode eksperimen laboratorium diperoleh rata-rata kadar flavonoid yang terkandung dalam daun lamun Enhalus acoroides sebesar 3,569\%.

Kesimpulan: Daun lamun Enhalus acoroides yang diambil dari perairan pantai Desa Waai terdapat senyawa flavonoid dengan nilai rata-rata sebesar 3,5697\%.
\end{abstract}

Kata kunci: Flavonoid, Enhalus acoroides 


\section{PENDAHULUAN}

Dunia tumbuhan memiliki beragam spesies yang tersebar di seluruh permukaan bumi, mengkolonisasi mulai dari daratan hingga perairan tawar dan lautan. Bukti yang ada menunjukkan bahwa tumbuhan angiospermae mulai mengkolonisasi lingkungan laut sekitar 100 juta tahun yang lalu (Den Hartog dalam Hemminga dan Duarte, 2000). Lamun (Seagrasses) adalah tumbuhan berbunga (Angiospermae) yang sudah sepenuhnya menyesuaikan diri hidup terbenam di dalam laut (Dahuri, 2003).

Jumlah spesies lamun di seluruh dunia adalah 50 spesies yang merupakan anggota dari 12 genus dari 4 famili (Nontji, 2005). Dari total 50 spesies lamun, 20 spesies di antaranya terdapat di Asia Timur yang meliputi Korea, Jepang dan Taiwan (Husein, 2009). Kelimpahan lamun tertinggi di dunia, ditemukan pada daerah tropis mencakup 7 genus antara lain Enhalus, Thalasia, dan Halophilla dari family Hidrocharitaceae, Holodule, Cimocodea, Syringodium, Thallasodendrom dari family Patomogetonaeae. Di daerah temperata hanya terdapat 5 marga lamun yaitu Halophilla, Syringodium, Thallasodendrom, Cymocodea, dan Zotera. Perbedaan jumlah lamun antara, daerah tropis dan temperata disebabkan oleh perbedaan faktor lingkungan perairan kedua daerah tersebut. Daerah temperate memilimki suhu yang rendah dan radiasi sinar matahari yang minimum, sedangkan daerah tropis memiliki suhu yang tinggi, radiasi sinar matahari maksimal, dan salinitas yang cenderung normal (Nontji, 2005).

Di perairan Indonesia trdapat 7 genus lamun yang merupakan anggota dari family Hydrocharitaceae dan Potamogenotaceae (Fahrudin, 2002). Keanekaragaman spesies lamun tertinggi di Indonesia dijumpai di perairan teluk Flores dan Lombok yang terdiri atas masing-masing 11 spesies (Husein, 2009). Daerah lain di Indonesia yang memiliki keanekaragaman spesies lamun yang tergolong tinggi adalah Sumatra, Jawa, Bali, Kalimantan yang terdiri atas masing-masing 10 spesies, sedangkan di daerah Nusa Tenggara dan Maluku masingmasing terdiri atas 9 spesies lamun (Dahuri, 2003). Khusus di perairan Maluku, ekosistem lamun dijumpai di Pulau Ambon,
Pulau Seram, Kepulauan Aru, Pulau Buru dan Pulau Saparua (Monk, 2000).

Ekosistem lamun memiliki fungsi secara ekologis dan secara ekonomis. Secara ekologis, lamun dimanfaatkan oleh biota perairan sebagai sumber makanan, tempat memijah, tempat asuhan, tampat perlindungan dan persembunyian dari panas matahari dan serangan pemangsa oleh berbagai ikan dan invertebrata (Notji, 2005; Dahuri, 2003). Selain itu, ekosistem lamun juga berfungsi sebagai penangkap sendimen, pelindung pantai, dan peredam arus gelombang (Dahuri, 2003; Fahrudin, 2002; Monk, 2000; Nontji, 2005).

Sebagai sumber makanan, daun lamun spesies Thalasia $s p$ dan Syringodium isoetifollium secara langsung dikonsumsi oleh ikan beronang (Siganus canliculatus), penyu hijau (Chelonia midas), gastropoda spesies Strombus sp, bulu babi spesies Tripneustes gratilla dan Temopleurus foreumatikus, sedangkan daun lamun spesies Halodule sp, Cimocodea sp dan Zhamia sp dikonsumsi oleh ikan duyung (Dugong dugong). Sebagian besar bahan organik (65-85\%) dalam bentuk detritus yang diproduksi oleh lamun dan dimanfaatkan oleh alga epifit sebagai sumber nutrien dengan cara melekatkan dirinya pada daun lamun (Fahrudin, 2002) selanjutnya alga epifit dimanfaatkan oleh juvenile udang dan ikan, gastropoda, crustaceae dan polichaeta sebagai sumber makanan (Susetiono, 2004).

Adaptasi biokimia yang dilakukan oleh golongan tumbuhan umumnya termasuk lamun ialah dengan menghasilkan atau mengeluarkan senyawa tertentu yang disebut senyawa bioaktif atau metabolit sekunder. Senyawa-senyawa kimia ini menurut Subhashini et al. (2013), di sintesis oleh jalur metabolik sekunder yang tidak terlibat dalam pertumbuhan normal, perkembangan atau reproduksi tetapi biasanya memiliki peran dalam proses adaptasi dalam kondisi stress.

Beberapa penelitian telah mendokumentasikan kelimpahan metabolit alam (metabolit sekunder, senyawa bioaktif) ini di lamun dan beberapa telah difokuskan pada potensi bioaktif mereka (Subhashini et al., 2013) diantaranya yaitu, penelitian oleh Santoso et al. (2012), menemukan senyawa metabolit sekunder seperti saponin, 
triterpena dan sterol pada ekstrak etanol $80 \%$ di 7 spesies lamun. Pada ekstrak methanol lamun Syringodium isoetifolium oleh Mani et al. (2012), ditemukan beragam senyawa metabolit sekunder seperti saponin, fenol dan alkaloid.

Banyak kandungan metabolit sekunder dari lamun telah diketahui aktif secara biologis dan merupakan biomedis penting serta bisa dimanfaatkan sebagai obat yang potensial. Akar dari Enhalus acoroides digunakan sebagai obat terhadap sengatan berbagai jenis pari dan kalajengking. Halophila sp. adalah obat yang ampuh terhadap penyakit malaria, penyakit kulit dan ditemukan sangat efektif dalam tahap awal kusta (Mani et al., 2012). Pada daerahdaerah maritim Asia, ekstrak lamun digunakan sebagai agen kuratif berbagai penyakit seperti antibiotik, antihelmintic, batuk, antipiretik, antitumor, antidiarea, penyembuhan luka, pengobatan batu empedu dan gondok (Umamaheshwari dkk., 2009).

Flavonoid terdapat pada seluruh bagian tanaman, termasuk pada daun lamun Enhalus acoroides. Flavonoid didalam tumbuhan biasanya terikat dengan gugus gula sebagian glikosida dan aglikogen dalam beberapa bentuk kombinasi glikosida. Flavonoid juga mengandung sistem aromatik terkonjugasi sehingga akan menunjukan serapan kuat pada daerah spektrum sinar UV dan spektrum sinar tampak (Harborne, 1987). Aglikon flavonoid merupakan pelifenol yang mempunyai sifat kimia yang sama seperti senyawa fenol yaitu memiliki sifat agak asam sehingga dapat larut dalam basa. Flavonoid yang telah diisolasi dari tumbuhan mempunyai berbagai keaktifan biologis anatara lain mempunyai keefektifan sebagai obat, insektisida, anti mikroba, anti virus, anti jamur, obat infeksi pada luka, mengurangi pembekuan darah di dalam tubuh, mempercepat pembekuan darah di luar tubuh, merangsang pembentukan estrogen pada mamalia, antihipertensi, antioksidan, anti tumor, dan kanker (Robinson, 1995).

Karakteristik lamun berbeda untuk setiap faktor ekologis sehingga memungkinkan tiap daerah memiliki variasi spesies lamun. Perairan pantai desa Waai merupakan perairan yang berada di Kecamatan Salahutu, Kabupaten Maluku
Tengah. Perairan ini merupakan bagian dari perairan pulau Ambon yang berhadapan langsung dengan Pulau Haruku. Profil substrat dari perairan pantai desa Waai yaitu pasir berlumpur, pasir berbatu dan pecahan karang mati. Potensi sumberdaya pesisir yang ada di daerah tersebut cukup banyak diantaranya lamun (Seagrass). Di perairan pantai Desa Waai terdapat sebanyak 4 spesies lamun yang merupakan anggota dari 1 ordo, 2 famili dan 4 genus (Wakano, 2014). Kajian literatur mengenai senyawa flavonoid dari lamun Enhalus acoroides yang ada di pantai desa Waai hingga saat ini belum ada.

Berdasarakan latar belakang di atas, maka perlu dilaakukan penelitian tertarik analisis senyawa flavonoid pada daun lamun Enhalus acoroides di perairan pantai desa waai kabupaten maluku tengah.

\section{MATERI DAN METODE Waktu dan Tempat}

Penelitian ini dilakukan di Laboratorium Kimia Dasar, Fakultas Matematika dan IImu Pengetahuan Alam (FMIPA) Universitas Pattimura Ambon. Penelitian dilakukan mulai dari tanggal 20 sampai dengan 28 maret 2016, dengan lokasi pengambilan sampel di perairan pantai Desa Waai Kabupaten Maluku Tengah.

\section{Alat dan Bahan}

Alat yang digunakan dalam penelitian ini, Blender, Katung plastic, Elyemeyer 1000 $\mathrm{ml}$, Gelas ukur $10 \mathrm{ml}, 100 \mathrm{ml}$, Labu ukur 10 $\mathrm{ml}, 100 \mathrm{ml}$, Spatula, Gelas beker $500 \mathrm{ml}$, Rotary evaporator, Vial $15 \mathrm{ml}$, Corong, Neraca analitik, Tabung reaksi, Rak tabung reaksi, Pipet ukur $5 \mathrm{ml}$, Mikropipet, Scaple, Batang pengaduk, Spektrofotometer UVVIS, Kertas saring.

Bahan yang digunakan dalam penelitian ini, Daun lamun Enhalus acoroides, HCL $5 \%$, Methanol, Akuades, Amoniak, Natrium hidroksida, Alkohol, $\mathrm{CH}_{3} \mathrm{COOK} 1 \mathrm{M}, \mathrm{AlCl}_{3}$ $10 \%$, Kuersetin.

Yang menjadi objek dalam peneitian ini adalah 65 gram daun lamun Enhalus acoroides 


\section{Prosedur Penelitian}

\section{Preparasi Sampel}

a) Daun lamun jenis Enhalus acoroides diambil di perairan Desa Waai.

b) Sampel diletakan di dalam wadah yang berisi air laut perairan tempat hidupnya, bertujuan untuk menjaga kelangsungan hidup lamun selama proses transportasi ke laboratorium.

c) Daun lamun dibersihkan dari pasir dan kotoran-kotoran dengan menggunakan air tawar.

d) Daun lamun yang telah dibersihkan lalu direndam ke dalam larutan HCL 5\% di dalam wadah tertutup sambil sesekali diaduk selama 1 jam. Lamun yang telah direndam lalu dicuci lagi menggunakan air mengalir dan epifhit yang ditemukan dikeruk secara hati-hati menggunakan scapel.

e) Lamun yang sudah dibersihkan, dikeringkan dengan oven pada suhu $60^{\circ} \mathrm{C}$ selama 3 jam.

f) Daun lamun yang telah kering dihaluskan dengan blender, kemudian disaring untuk mendapatkan butiran yang seragam, dimasukkan dalam kantong plastik disimpan dalam kondisi kering untuk selanjutnya dilakukan proses ekstraksi. Sediaan daun lamun kering ini disebut simplisia.

2. Ekstraksi Maserasi (Juniarti et al., 2009; Santoso, et al., 2012)

a) Ekstraksi menggunakan metanol.

b) Ekstraksi dilakukan dengan menggunakan Metode Maserasi dengan 3 kali pengulangan.

c) Sampel direndam dengan perbandingan berat sampel dan volume pelarut 1:10 selama 3x24 jam.

d) Larutan ekstrak yang didapat di saring menggunakan kertas penyaring Whatman No.1. Filtrat yang diperoleh kemudian dipekatkan dengan vacuum rotary evaporator pada suhu $40^{\circ} \mathrm{C}$ hingga diperoleh ekstrak kasar (crude extract) berupa pasta.

\section{Uji Flavonoid}

Sejumlah sampel ditambah $0,1 \mathrm{mg}$ amoniak, 0,4 $\mathrm{mL}$ natrium hidroksida dan 4 $\mathrm{mL}$ alkohol, kemudian campuran dikocok. Adanya flavonoid ditunjukkan dengan terbentuknya warna merah, kuning atau jingga pada lapisan natrium hidroksida (Harborne dalam Priyanto, 2012).

\section{Analisis Kandungan Total Flavonoid}

Metode yang digunakan mengacu pada metode Chang et al. (2002), Hassan et al. (2013) dan Nugroho et al. (2013) dengan menggunakan pereaksi $\mathrm{AlCl}_{3}$. Sebanyak 0.5 $\mathrm{ml}$ ekstrak $E$. acoroides dengan konsentrasi 1000 ppm dipipet kedalam tabung reaksi, ditambahkan $1,5 \mathrm{ml}$ metanol, $0,1 \mathrm{ml} \mathrm{AlCl}_{3}$ $10 \%, 0,1 \mathrm{ml} \mathrm{CH}_{3} \mathrm{COOK} 1 \mathrm{M}$ dan $2,8 \mathrm{ml}$ akuades. Larutan dihomogenkan dan diinkubasi selama 30 menit. Absorbansi larutan diukur dengan spektrofotometer UVVis pada panjang gelombang $430 \mathrm{~nm}$. Pengukuran absorbansi dilakukan 3 kali ulangan.

Kuersetin digunakan sebagai standar dengan seri konsentrasi 2 ppm, 4 ppm, 6 ppm, 8 ppm dan 10 ppm. Menurut Hassan et al. (2013), dan Nugroho et al. (2013), kurva kalibrasi kuersetin digunakan untuk menentukan kadar senyawa total flavonoid yang terkandung dalam sampel melalui persamaan regresi dan dinyatakan dalam satuan mg ekuivalen kuersetin/g ekstrak (mg $\mathrm{GAE} / \mathrm{g}$ ekstrak) dengan rumus sebagai berikut:

$$
\text { Total flavonoid }=\frac{\text { Berat flavonoid }}{\text { Berat sampel }} \times 100 \%
$$

\section{HASIL DAN PEMBAHASAN Hasil}

Berdasarkan hasil penelitian maka dapat dijelaskan sebagai berikut. Sebanyak $65 \mathrm{~g}$ daun $E$. acoroides segar dikeringkan dalam oven pada suhu $60^{\circ} \mathrm{C}$ selama 3 jam menjadi $37 \mathrm{~g}$. Ekstraksi menggunakan metanol sampel direndam dengan perbandingan 1:10 selama $3 \times 24$ jam. Ekstraksi menggunakan metanol karena flavonoid merupakan senyawa polar yang mempunyai sejumlah gugus hidroksil yang tak tersulih atau suatu gula, sehingga akan larut dalam pelarut polar seperti metanol. Adanya gula yang terikat pada flavonoid cenderung menyebabkan flavonoid lebih mudah larut dalam air dan dengan demikian campuran pelarut di atas dengan air merupakan pelarut yang lebih baik untuk glikosida (Markham, 1988). 
Untuk mendapatkan gambaran tentang hasil penelitian ini maka dibuat dalam bentuk kurva standar. Kurva standar adalah kurva yang dibuat berdasarkan konsentrasi standar dan nilai absorbansi standar. Kurva larutan standar kuersetin diperoleh dengan mengukur absorbansi dari larutan standar kuersetin, pada berbagai konsentrasi dan panjang gelombang maksimum yang telah ditentukan sebelumnya yaitu sebesar 430 $\mathrm{nm}$. Data larutan standar dan absorbansinya dapat dilihat pada Tabel 4.1 berikut.

Tabel 4.1. Absorbansi Larutan Standar Kuersetin.

\begin{tabular}{cc}
\hline Konsentrasi & Absorbansi \\
\hline $2 \mathrm{mg}$ & 0,143 \\
$4 \mathrm{mg}$ & 0,290 \\
$6 \mathrm{mg}$ & 0,428 \\
$8 \mathrm{mg}$ & 0,571 \\
$10 \mathrm{mg}$ & 0,717 \\
\hline
\end{tabular}

Setelah diperoleh absorbansi dari larutan standar, data diolah menjadi grafik antara kuersetin larutan standar kuersetin dan absorbansinya. Adapun kurva standar kuersetin dapat dilihat pada grafik 4.1 berikut:

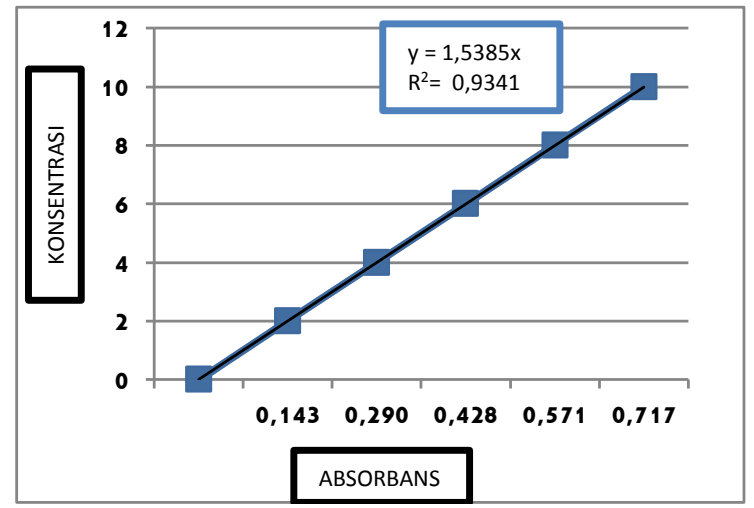

\section{Grafik 4.1. Kurva konsentrasi dan Absorbansi Standar.}

Berdasarkan grafik kalibrasi yang telah dibuat, terlihat bahwa grafiknya berupa garis lurus. Hal ini menunjukan bahwa semakin besar konsentrasi semakin besar pula nilai absorbansinya. Dari hasil pengukuran absorbansi pada tiap konsentrasi larutan standar kuersetin dan pengukuran absorbansi pada konsentrasi setiap kali pengulangan, maka dapat dihitung konsentrasi dari tiap pengulangan yang ditunjukan pada tabel 4.2 berikut:

Tabel 4.2. Absorbansi Cuplikan Pada Daun Lamun Enhalus acoroide (3X pengulangan).

\begin{tabular}{ccc}
\hline No & Konsentrasi & Absorbansi \\
\hline 1 & 7,25 & 0,516 \\
2 & 7,05 & 0,498 \\
3 & 7,20 & 0,513 \\
\hline
\end{tabular}

Setelah diperoleh absorbansi dari larutan sampel, data diolah menjadi grafik anatara konsentrasi cuplikan dengan absorbasinya. Adapun kurva cuplikan dapat dilihat pada grafik 4.2 berikut:

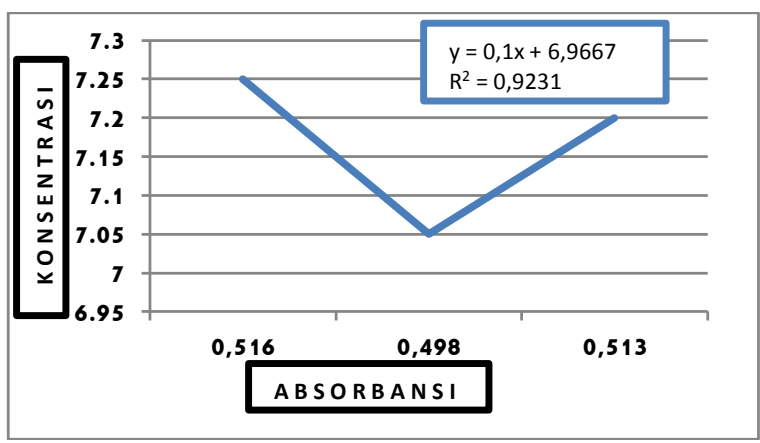

\section{Grafik 4.2. Kurva Konsentrasi Cuplikan dan Absorbansi Cuplikan.}

Telah dijelaskan pada grafik 4.1 bahwa absorbansi merupakan fungsi yang besarnya berbanding lurus dengan konsentrasi. Jadi semakin besar nilai konsentrasi maka semakin besar pula nilai absorbansinya. Pada Garfik 4.2 terlihat bahwa garis liniernya tidak berupa garis lurus seperti pada Grafik 4.1, hal ini disebabkan oleh jumlah konsentrasi pada ulangan II lebih kecil dibandingkan dengan jumlah konsentrasi pada ulangan III dan I. Jadi, besarnya nilai absorbansi tergantung pada besarnya nila konsentrasi.

Pada Grafik 4.2 terbaca bahwa nilai $\mathrm{R}^{2}=0,923$. Hal ini diartikan bahwa $92,31 \%$ variasi $Y$ (absorbansi) dapat diterangkan oleh variasi $X$ (konsentrasi), atau dapat diartikan bahwa 92,31\% dari variabel tak bebas $Y$ (absorbansi) dipengharui oleh variabel bebas $X$ (konsentrasi). Sisanya $7,69 \%(100 \%-92,31 \%)$ dari variasi total $Y$ (absorbansi) dipengharui oleh faktor lain diluar $\mathrm{X}$ (konsentrasi) atau variabel selain $\mathrm{X}$. 
Hasil analisis senyawa flavonoid daun lamun Enhalus acoroides pada perairan pantai Desa Waai dapat dilihat pada tabel 4.3.

Tabel 4.3 Senyawa Flavonoid Daun Lamun Enhalus acoroides

\begin{tabular}{cccccc}
\hline No & Ulangan & $\begin{array}{c}\text { Berat Sampel } \\
\text { (gram) }\end{array}$ & $\begin{array}{c}\text { Berat Flavonnoid } \\
\text { (gram) }\end{array}$ & $\begin{array}{c}\text { Kadar Flavonoid } \\
\text { (\%) }\end{array}$ & $\begin{array}{c}\text { Rata-rata kadar } \\
\text { flavonoid (\%) }\end{array}$ \\
\hline 1 & I & 10,0213 & 362,5 & 3,6172 & \\
2 & II & 10,0516 & 352,5 & 3,5069 & 3,5697 \\
3 & III & 10,0417 & 360,0 & 3,5850 & \\
\hline
\end{tabular}

\section{Pembahasan}

Berdasarkan hasil analisis maka diperoleh rata-rata kadar flavonoid pada daun lamun Enhalus acoroides yang diambil dari perairan pantai desa Waai kabupaten Maluku Tengah sebesar 3,569\%.

Penelitian yang dilakukan oleh Lumbessy dkk. (2013), menunjukan total flavonoid dari beberapa tanaman obat diantaranya daun rumput mutiara (Oldenlandia corymbosa) sebesar 2.686 $\mathrm{mg} / \mathrm{mL}$, rumput teki (Cyperus rotundus $\mathrm{L}$ ) kecuali akar sebesar 6.504 , daun pegagan (Centella asiatica) sebesar $3.816 \mathrm{mg} / \mathrm{mL}$, daun iler (Coleus scutellariodes $L$ benth) sebesar $14.246 \mathrm{mg} / \mathrm{mL}$, daun ketepeng (Cassia alata L) $26.8633 \mathrm{mg} / \mathrm{mL}$ dan daun waru (Hibiscus tiliaceus L) $1.425 \mathrm{mg} / \mathrm{mL}$.

Keberadaan senyawa flavonoid dalam tanaman berbeda-beda dapat disebabkan oleh beberapa faktor diantaranya perbedaan kondisi lingkungan tempat tumbuh, suhu, sinar ultraviolet, unsur hara, ketersediaan air dan kadar $\mathrm{CO}_{2}$ dalam atmosfer (Bhat et al., 2009).

Karakteristik lokasi pengambilan sampel di perairan pantai desa Waai sebagai berikut. Enhalus acoroides tumbuh pada substrat pasir berlumpur pada kedalaman 2 meter saat air pasang. Suhu $28,30^{\circ} \mathrm{C}$, nilai salinitas 28,63\%o, kandungan oksigen terlarut 5,71 ppm, kadar nitrat perairan 1,14 ppm, dan kadar fosfat 0,53 ppm.

Pada perairan alami kecerahan sangat penting karena erat kaitannya dengan proses fotosintesis. Kebutuhan cahaya yang tinggi bagi lamun untuk fotosintesis terlihat dari sebarannya yang terbatas pada daerah yang masih menerima cahaya matahari. Nilai kecerahan perairan sangat dipengaruhi oleh kandungan lumpur, plankton, dan zat terlarut lainnya (Nybakken, 1992). Enhalus acoroides yang diambil dari perairan pantai desa Waai untuk dijadikan objek penelitian berada pada kedalaman $2 \mathrm{~m}$ sangat baik untuk pertumbuhan lamun. Semakin tinggi nilai kecerahan maka akan tinggi pula tingkat penetrasi cahaya ke dalam perairan. Penetrasi cahaya matahari atau kecerahan sangat penting bagi tumbuhan lamun. Hal ini terlihat dari sebaran lamun yang terbatas pada daerah yang masih menerima cahaya matahari (Nybakken, 1992).

Suhu merupakan salah satu faktor yang sangat penting dalam mengatur proses kehidupan. Suhu di perairan pantai desa waai pada lokasi pengambilan sampel sangat cocok untuk proses pertumbuhan lamun yaitu $28,30^{\circ} \mathrm{C}$. Hutomo (1999), menjelaskan bahwa perubahan suhu terhadap kehidupan lamun antara lain dapat mempengaruhi metabolisme, penyerapan unsur hara dan kelangsungan hidup lamun. Pada kisaran suhu $25-30^{\circ} \mathrm{C}$, fotosintesis akan meningkat dengan meningkatnya suhu (Hutomo, 1999).

Salinitas adalah total konsentrasi ion-ion yang terlarut dalam air. Salinitas dinyatakan dalam satuan promil $(\% 0)$. Pada perairan pesisir nilai salinitas sangat dipengaruhi oleh masuknya air tawar dari sungai. Nilai salinitas di perairan pantai desa waai $28,63 \%$ dan ini merupakan nilai salinitas yang cocok untuk pertumbuhan lamun. Hutomo (1999), menjelaskan bahwa lamun memiliki kemampuan toleransi yang berbeda terhadap salinitas, namun sebagian besar memiliki kisaran yang lebar yaitu $10-40 \% 0$. Nilai salinitas yang optimum untuk lamun adalah $35 \% 0$. Walaupun spesies lamun memiliki toleransi terhadap yang berbedabeda, namun sebagian besar memiliki kisaran yang besar terhadap salinitas yaitu antara $10-30 \% 0$. Penurunan salinitas akan menurunkan kemampuan fotosintesis (Dahuri, 2001).

Di perairan pantai desa Waai pada lokasi pengambilan sampel lamun Enhalus 
acoroides ditemukan tumbuh pada substrat pasir berlumpur. Ini adalah substrat yang baik dan cocok untuk pertumbuhan lamun Enhalus acoroides. Erftemeijer and Middelburg (1993), menjelaskan bahwa laju pertumbuhan daun dan produksi lamun Enhalus acoroides lebih tinggi pada substrat lumpur berpasir (sedimen terigenous) dibandingkan pada jenis substrat yang lain, karena substrat lumpur berpasir umumnya mempunyai ketersediaan unsur hara $\mathrm{N}$ dan $P$ yang lebih tinggi Ketersediaan unsur hara $\mathrm{N}$ dan $\mathrm{P}$ pada substrat tersebut berkaitan dengan ukuran partikel dan ketebalan sedimen. Semakin kecil ukuran sedimen, maka akan semakin besar ketersediaan unsur hara $\mathrm{N}$ dan $\mathrm{P}$ di substrat tersebut.

Ketersediaan nutrien di perairan padang lamun merupakan faktor pembatas pada pertumbuhan lamun. Nutrien dapat ditemukan pada kolom perairan maupun dalam sedimen. Di perairan pantai desa Waai tempat pengambilan sampel daun lamun Enhalus acoroides kadar nitrat perairan 1,14 ppm. Penelitian yang dilakukan oleh McRoy \& Barsdate dalam Kiswara (1995), menunjukkan bahwa lamun mempunyai kemampuan mengambil nutrisi melalui daun dan akarnya. Elemen penting yang diperlukan oleh lamun adalah nitrogen $(\mathrm{N})$, fosfat $(\mathrm{P})$ dan C-organik. $\mathrm{N}$ dan $\mathrm{P}$ yang banyak digunakan oleh lamun adalah nitrat, ammonium dan orthofosfat (Badria, 2007). Nitrat $\left(\mathrm{NO}_{3}\right)$ adalah bentuk utama nitrogen di perairan alami dan merupakan nutrien utama pada ekosistem padang lamun (Effendi, 2003). Menurut Philips dan Menez dalam Badria (2007), pertumbuhan lamun berasal dari daur ulang nitrogen dalam sedimen dan kolom perairan. Rizoma dan akar lamun yang mati menambahkan kadar nitrat dalam sendimen.

Fosfat merupakan bentuk fosfor yang dapat dimanfaatkan oleh tumbuhan. Fosfor merupakan unsur esensial bagi tumbuhan sehingga unsur ini merupakan faktor pembatas bagi tumbuhan tingkat tinggi dan alga akuatik serta sangat mempengaruhi tingkat produktifitas perairan (Effendi, 2003). Di perairan pantai desa Waai kadar fosfat $0,53 \mathrm{ppm}$ dan ini sangat baik untuk pertumbuhan lamun. Menurut Mcroy et al. dalam Kiswara (1995), fosfat dalam sedimen adalah sumber utama untuk pertumbuhan lamun. Fosfat diserap oleh akar kemudian dialirkan ke daun dan dipindahkan ke perairan sekitarnya. Penelitian yang dilakukan oleh Ohorella (2011), mendapatkan hasil bahwa laju pertumbuhan Enhalus acoroides lebih tinggi pada perairan dengan konsentrasi fosfat yang lebih tinggi dibandingkan pada perairan dengan kandungan fosfat yang lebih rendah. Oleh karena itu, fosfat merupakan salah satu nutrien yang dibutuhkan oleh lamun dalam proses pertumbuhan, jadi apabila ketersediaan fosfat kurang akan menghambat pertumbuhan lamun.

Penelitian yang dilakukan oleh Santos (2004), menunjukan bahwa penurunan produksi hasil fotosintesis yaitu glukosa merangsang aktifitas enzim PAL (Phenylalanine AmmoniaLyase). Enzim PAL merupakan prekursor biosintesis senyawa flavonoid.

Ketika laju fotosintesis rendah dan produksi glikosa berkurang maka aktifitas enzim PAL akan meningkat dan diikuti dengan biosintesis flavonoid. Selain itu, meningkatnya konsentrasi $\mathrm{CO}_{2}$ mampu meningkatkan laju fotosintesis namun sebaliknya menurunkan total flavonoid (Discosmo dan Towers, 1984).

Senyawa flavonoid adalah golongan senyawa yang tidak tahan panas dan mudah teroksidasi pada suhu tinggi. Penelitian yang dilakukan oleh Santoso (2014), terhadap kadar total flavonoid buah kiwi menunjukan bahwa suhu yang tinggi dapat merusak flavonoid. Disebabkan karena flavonoid yang berbentuk glikosida terhidrolisis menjadi aglikon. Hal ini sesuai penelitian Redha (2010), bahwa hidrolisis glikosida antasianin dalam kondisi asam mengahasilkan aglikon antosianidin.

Keberadaan kadar flavonoid juga dipengaruhi oleh ketersediaan air. Flavonoid merupakan senyawa polar yang larut dalam pelarut polar seperti methanol, etanol, butanol, dan air. Adanya gula yang terikat pada flavonoid cenderung menyebabkan flavonoid lebih mudah larut dalam air (Harborne, 1987). Berdasarkan hasil penelitian Timisela (2015), pengujian golongan flavonoid pada lamun menunjukan flavonoid dapat larut dalam pelarut yang kepolarannya lebih tinggi seperti air karena flavonol memiliki kelebihan gugus hidroksil pada posisi samping. 
Hasil penelitian Timisela (2015), menunjukan rata-rata kadar flavonoid yang terkandung dalam daun lamun Enhalus acoroides yang terdapat di desa Galala sangat rendah, yaitu $0,0192 \%$. Rendahnya kadar flavonoid yang terkandung dalam daun lamun Enhalus acoroides yang terdapat di desa Galala ini disebakan karena perairan desa Galala tergolong perairan tercemar. Hal ini dibuktikan dengan kondisi perairan yang tidak lagi jernih dan tingkat logam berat yang tinggi. Keadaan ini disebabkan karena banyaknya pabrik dan perusahaan yang beroperasi membuang limbah hasil produksi ke perairan desa Galala. $\mathrm{CO}_{2}$ diproduksi dalam jumlah yang besar pada air yang tercemar (Tuwo, 2011). Rendahnya kandungan flavonoid yang terdapat pada daun lamun di perairan desa Galala menunjukan pengaruh konsentrasi $\mathrm{CO}_{2}$ yang tinggi pada perairan ini sehingga meningkatkan laju fotosintesis sebaliknya menurunkan total flavonoid.

Hasil penelitian Rizal (2010), menunjukan tingkat bioakumulasi logam berat timbal $(\mathrm{Pb})$ dan cadmium $(\mathrm{Cd})$ pada lamun Enhalus acoroides di perairan desa Galala mencapai $7.23 \%$ dan akumulasi yang tertinggi ditemukan pada daun lamun. $\mathrm{Pb}$ dan Cd yang bersifat basa berpengaruh pada flavonoid. Hal ini dikarenakan sifat kimia flavonoid yang bersifat asam sehingga dapat larut dalam basa (Singh et al., 2003). Tingginya kandungan $\mathrm{Pb}$ dan $\mathrm{Pb}$ yang terdapat pada lamun Enhalus acoroides menyebabkan larutnya kandungan flavonoid pada daun lamun Enhalus ancoroides di perairan desa Galala. Selain itu, perairan desa Galala yang bersifat basa menyebabkan kadar $\mathrm{CO}_{2}$ meningkat (Tuwo, 2011).

Berdasarkan hasil survei perairan desa Waai termasuk dalam perairan yang cukup stabil dan belum tercemar. Hal ini disebabkan karena perairan ini bukanlah merupakan perairan yang menjadi pusat kegiatan manusia seperti perkapalan dan pembuangan sisa industri dan rumah tangga. Faktor kondisi lingkungan tempat tumbuh Enhalus acoroides di perairan desa Waai inilah yang menyebabkan kadar flavonoid lebih tinggi dibandingkan kadar flavonoid di perairan desa Galala.

\section{KESIMPULAN DAN SARAN \\ Kesimpulan}

Dari hasil penelitian dapat disimpulkan bahwa daun lamun Enhalus acoroides yang diambil dari perairan pantai desa Waai terdapat senyawa flavonoid dengan nilai rata-rata sebesar 3,569\%.

\section{Saran}

1. Perlu dilakukan penelitian lanjut tentang analisis senyawa flavonoid pada lamun Enhalus acoroides di perairan desa lain serta menggunakan bagian lain dari tubuh lamun Enhalus acoroides.

2. Diharapkan ada penelitian lanjutan untuk pengembangan sehingga lamun bisa dimanfaatkan secara optimal sebagai sumber makanan kesehatan.

3. Bagi masyarakat desa Waai khususnya para nelayan untuk tidak mengambil lamun Enhalus acoroides secara sembarangan agar keberadaan lamun Enhalus acoroides diperairan pantaai desa Waai tetap terlestarikan.

\section{DAFTAR PUSTAKA}

Badria, S. 2007. Laju Pertumbuhan Daun Lamun (Enhalus acroides) pada Dua Substrat Yang Berbeda Di Teluk Banten (Skripsi). Program Studi IImu dan Teknologi, Fakultas Perikanan dan IImu Kelautan. Institut Pertanian Bogor.

Bhat, S. V., B. A. Nagasampagi and S. Meenakshi. 2009. Natural Products: Chemistry and Application. Narosa Publishing House: New Delhi.

Chang, C. C., M. H. Yang, H. M. Wen and J. C. Chern. 2002. Estimation of Total Flavonoid Content in Propolis by Two Complementary Colorimetric Methods. Journal of Food and Drug Analysis, 10 (3): 178-182.

Dahuri, R. 2001. Pengelolaan Sumber Daya Wilayah Pesisir dan Lautan Secara Terpadu. Pradnya Paramita: Bogor.

Dahuri, R., 2003, Keanekaragaman Hayati Laut: Aset Pembangunan Berkelanjutan Indonesia, PT Gramedia Pustaka Utama: Jakarta.

Dicosmo. F. and Towers, G. H. N. 1984, Stress and Secondary Metabolism in Cultured Plant Cells, in: Phytochemical Adaptation and Stress (Timmeremann 
et al, editors), 97-150, Plenum Publishing Co., Toronto.

Effendi, H. 2003. Telaah Kualitas Air Bagi Pengelola Sumberdaya dan Lingkungan Perairan. Kanisius: Yogyakarta.

Fahrudin. 2002. Pemanfaatan, Ancaman, dan Isu-isu Pengelola Ekosistem Padang Lamun: http://tumoutou.net Diakses 25 Agustus 2015.

Harborne, J. B. 1987. Metode Fitokimia: Penuntun Cara Modern Menganalisis Tumbuhan. Institut Teknologi Bandung, Bandung (diterjemahkan oleh Kosasih Padmawinata dan Iwang Soediro).

Hassan, S. M., A. A. Al Aqil and M. Attimarad. 2013. Determination of Crude Saponin and Total Flavonoids Content in Guar Meal. Advancement in Medicinal Plant Research, 1 (2) : 24-28.

Hemminga, A dan C., Duarte, 2000, Seagrass Ecology. Cambridge University Press: Cambridge.

Hutomo, M. 1999. Proses Peningkatan Nutrient Mempengaruhi Kelangsungan Hidup Lamun. LIPI: Jakarta

Hussein, A. 2009. Sejenak Kita Serius Untuk Me"Lamun": $\quad$ http://muhamaze. worpress.com. Diakses, 25 Agustus 2015.

Juniarti, D. Osmeli dan Yuhernita. 2009. Kandungan Senyawa Kimia, Uji Toksisitas (Brine Shrimp Lethality Test) dan Antioksidan (1,1-diphenyl- 2pikrilhydrazyl) dari Ekstrak Daun Saga (Abrus precatorius I.). Makara Sains, 13 (1): 50-54

Kiswara W, 1995. Kandungan Hara dalam Air Antara dan Air Permukaan Padang Lamun Pulau Barrang Lompo dan Gusung Talang, Sulawesi Selatan. Balitbang, Biologi, Pustlitbang Oseanologi, LIPI. Jakarta Timur.

Lumbessy, M., J. Abidjulu, dan Jessy J. E. Paendong. 2013. Uji Total Flavonoid Pada Beberapa Tanaman Obat Tradisonal Di Desa Waitina Kecamatan Mangoli Timur Kabupaten Kepulauan Sula Provinsi Maluku Utara. Jurusan Kimia FMIPA. Unsrat: Manado.

Mani, A. E. Aiyamperumal, V dan Patterson, J., 2012, Phytochemicals of The Seagrass Syringodium Isoetifolium and Its Antibacterial And Insecticidal Activities, European Journal of Biological Sciences
Markham K. R. 1988. Cara Mengidentifikasi Flavonoid. Kosasih $\mathrm{P}$, penerjemah. Bandung: Institut Teknologi Bandung.

Monk, K. A. 2000. Ekologi Nusatenggara dan Maluku. Prehallindo: Jakarta.

Nontji. 2005. Laut Nusantara Cetakan Keempat edisi Revisi: Djambatan Jakarta

Nugroho, A. E., A. Malik and S. Pramono. 2013. Total Phenoloc and Flavonoid Content, and In Vitro Antihypertension Activity of Purified Extract of Indonesian Cashew Leaves (Anacardium occidentale L.). International Food Research Journal, 20 (1): 299-305.

Nybakken JW. 1992. Biologi Laut Suatu Pendekatan Ekologis. Penerbit PT. Gramedia Jakarta.

Ohorella, A. 2011. Analisis Kandungan Fosfat dan Hubungannya Dengan Tingkat Pertumbuhan Daun Lamun Enhalus acoroides. Skripsi. Jurusan IImu Kulautan. Fakultas IImu Kelautan dan Perikanan. Universitas Hasanuddin: Makssar.

Priyanto, R. A., 2012, Aktivitas Antioksidan Dan Komponen Bioaktif Pada Buah Bakau (Rhizophora mucronata Lamk.), Skripsi, Institut Pertanian Bogor.

Redha, A. 2010. Flavonoid: Struktur, Sifat Antioksidan dan Peranannya Dalam Sisitim Biologis. Jurnal. Jurusan Teknologi Pertanian Politeknik Negri Pontianak: Pontianak.

Robinson, T. 1995. Kandungan Organik Tumbuhan Tinggi, ITB: Bandung.

Santos, C.V. 2004. Regulation off chlorophyll biosynthesis and degradation by salt stress in sunflower leaves. Sci. Hortic. 103:93-99.

Santoso 2014. Effect of Processing on Major Flavonoid in Processed Onion, Gren Beans and Peas: Food Chem

Santoso, J., S. Anwariyah, R. O. Rumiantin, A. P. Putri, N. Ukhty and Y. YoshieStark. 2012. Phenol Content, Antioxidant Activity and Fibers profile of Four Tropical Seagrasses from Indonesia. Journal of Coastal Development, 15 (2): 189-196.

Singh, B., T. K. Bhat, B. Singh. 2003. Potential Therapeutic Applications of Some Antinutritional Plant Secondary Metabolites. J. Agric. Food Chem, 51: 5579-5597. 
Subhashini, P. Dilipan, E. Thangaradjou, T dan Papenbrock, J., 2013, Bioactive Natural Products from Marine Angiosperm: Abundance and Functions, Natural Product Bioprospect: 129 - 136.

Susetiono. 2004. Fauna Padang lamun Tanjung Merah Selat Lembah. Pusat Jakarta: Penalitian Oseanografi-LIPI.

Timisela, P. P., 2015. Identifikasi dan Analisis Flavonoid Daun Lamun Enhalus acoroides Pada Perairan Pantai Desa Galala dan Rutong, [Skripsi]. FKIP Unpatti: Ambon
Tuwo, A. 2011. Pengelolaan Ekowisata Pesisir Dan Laut. Brilian Internasional. Indonesia.

Umamaheshwari, R. Thirumaran, G dan Anantharaman, P. 2009. Potential Antibacterial Activities of Seagrasses from Vellar Estuary; Southeast Coast of India Advances in Biological Research 3 (3-4): 140-143

Wakano, D, 2014 Inventarisasi Jenis-Jenis Lamun (Seagrass) Di Perairan Pantai Desa Waai Dan Desa Liang. Seminar Nasional Basic Science VI F-MIPA Unpatti Ambon. 